\title{
Гібридна війна - сучасна стратегія протистояння
}

\author{
Олег Посмітюх * 1 А; Микола Павлунько 2 А; Вадим Ковальській 3 А \\ А Національний університет оборони України імені Івана Черняховського, пр-кт Повітрофлотський, 28, г. Київ, 03049, Україна
}

Received: June 4, 2021 | Revised: June 20, 2021 | Accepted: June 30, 2021

DOI: $10.33445 /$ sds.2021.11.3.19

\begin{abstract}
Анотація
В статті розглянуті наукові публікації з досвіду протистояння проти гібридних загроз держав світу, на основі даних матеріалів визначені цілі, зміст гібридної війни та сформульовано ії̈ визначення.

Поява і розвиток нових стратегічних факторів породило концепт гібридної війни як стратегії протистояння між державами, який неможливо в чистому вигляді віднести ні до війни, ні до миру. Термін “гібридна війна" вперше надано в воєнних документах США i Великобританії на початку XXI сторіччя.

В сьогоднішніх війнах і збройних конфліктах, як на теренах України так і в інших регіонах світу проявляються домінуючі важливі риси та характеристики війн майбутнього. Вони все більше набуває гібридного (“комбінованого”) характеру. На даний час досвід АТО і ООС, показує, що ми зіткнулися з війною гібридного характеру, яку не можемо закінчити традиційними методами.
\end{abstract}

Ключові слова: гібридна війна, держава, національна безпека, збройний конфлікт, стратегічні дії.

\section{Постановка проблеми}

"Останні 25 років відбулися таки зміни у самому образі ведення воєнних дій, що наступна війна в самих суттєвих умовах не буде схожа на попередню".

І.С. Бліох “Будущая война" (1898р.)

у сьогоднішніх війнах і збройних конфліктах, як на теренах України так і в інших регіонах світу проявляються домінуючі важливі риси та характеристики війн майбутнього. Вони все більше набувають гібридного (“комбінованого") характеру. Керівні документи застосування Збройних Сил України та самі збройні сили розраховані на протистояння зі збройними силами традиційного типу на принципах воєнного мистецтва другої половини XX сторіччя 3 урахування фаз та етапів збройного конфлікту. Досвід АТО і ООС, показує, що ми зіткнулися з війною гібридного характеру, яку

\author{
не можемо закінчити традиційними \\ методами.
}

На даний час проводиться систематизація і аналіз знань з проблематики гібридної війни з урахуванням останніх подій в світі. Одним із елементів цієї роботи є визначення гібридної війни.

Визначення гібридної війни це не просто формальний академічний диспут, ці визначення зумовлюють, як держава повинна сприймати і відповідати на гібридні загрози, яка роль Збройних Сил України в цьому процесі.

\footnotetext{
1 *Corresponding author: к.в.н., доцент, e-mail: olegposmit777@gmail.com, ORCID: 0000-0002-4467-9532

2 K.B.H., e-mail: olegposmit777@gmail.com, ORCID: 0000-0001-8255-6245

${ }^{3}$ e-mail: olegposmit777@gmail.com, ORCID: 0000-0002-0234-4304
} 


\section{Аналіз останніх досліджень та публікацій}

В Україні питання гібридної війни розглядали в своїх роботах А. Курбан, Ю. Радковець, О. Левченко, В. Ліпкан, Л. Компанцева, І. Рижков, Н. Агаєв та інші. В своїх дослідженнях вони спираються на аналізі агресивних дій Росії. Кожен з них трактує термін “гібридна війна" виходячи 3 ракурсу свого фаху. У статті Л. Компанцевої [9] зібрані терміни (матриця) збройних конфліктів сучасності та розкритий їх зміст, особлива увага надана терміну організаційна війна. Всі ці роботи тільки спроба узагальнити досвід та сформулювати закони, закономірності гібридної війни.

Матеріали щодо гібридної війни українських авторів в основі своєї мають оборону направленість.

В Росії, з цього питання, вийшов воєннотеоретичний труд І. Попова і М. Хамзатова “Война будущего. Концептуальные основы и практические

выводы.

Очерки стратегической мысли". Це збірка статей, в яких широко розглядається коло питань щодо змісту, типології майбутніх війн, стратегії і тактики дій, форм і способів застосування збройних сил на практиці.

На Заході давно вже усвідомили, що сучасна війна це складне соціальне, політичне, психологічне, духовно-культурне, економічне, воєнне явище. Тільки в США за останніх десятиріччя розроблені велика кількість концепцій і теорій, середи них концепції: “обеззброюючого глобального високоточного удару", "мережецентрична війна", “війна трьох кварталів", концепція "стратегічного паралічу" і “п'яти кілець" полковника Джона Уордена, концепція "шоку і трепету", “культурологічна розвідка" і “соціальний ландшафт”, концепція “бойових зграй".

\section{Постановка завдання}

Мета статті. На основі аналізу наукових публікацій, досвіду протистояння проти гібридних загроз держав світу, сформулювати цілі, зміст гібридної війни та сформулювати її визначення.

\section{Виклад основного матеріалу}

Поява і розвиток нових стратегічних факторів породило концепт гібридної війни як стратегії протистояння між державами, який неможливо в чистому вигляді віднести ні до війни, ні до миру. Термін “Гібридна війна" вперше надано в воєнних документах США и Великобританії на початку XXI сторіччя. $[3,4]$

Але почнемо з похибки перекладу. В англомовних джерелах мова йде о "Hybrid Warfare", у нас же отримав широко поширення термін “гібридна війна". В англійській мові терміну війна відповідають два слова "war" і "warfare" але вони ні $\epsilon$ синонімами. Термін "war" за своїм змістом близький до слова "війна", а термін "warfare" - "воєнні дії”, "збройна боротьба".

Ще однією похибкою, яка здійснює пагубний вплив на прийнятий у вітчизняній воєнній теорії понятійний апарат, $\epsilon$ англомовний термін “Operations”. Справа, в тому, що термін “Operations" в більшості випадків необхідно перекладати як "дія".

Таке розуміння термінів не входить в протиріччя 3 понятійним апаратом вітчизняної воєнної теорії, але вносить де які непорозуміння.

У роботах вітчизняних авторів надані різні визначення терміну “гібридна війна".

Курбан А у роботі "Інформаційні війни в соціальних онлайн-мережах" [5] визначив гібридну війну як комбіноване, інтегроване воєнно-політичне і економічне протистояння у вигляді безстатусного, частіше скритого конфлікту. Звернув увагу на підвищення ролі невійськового впливу на противника за допомогою політичних (дипломатичних), економічних і гуманітарних елементів та зазначив, що інформаційна складова $\epsilon$ основою діяльності на всіх етапах конфлікту 
від підготовки до пост конфліктного періоду. Етапи гібридної війни: інноваційна агресія (кібернетична війна, економічний тиск, інформаційно-психологічні атаки тощо); застосування нерегулярних збройних формувань або приватних армій (повстанський, партизанській рухи, тероризм); офіційні воєнні дії або демонстрація сили (ідентифікована уніформа, зброя, офіційне визнання участі у конфлікті).

Радковець Ю. у роботі “Уроки дворічної “гібридної війни" Росії проти України" [6] надав наступне визначення - гібридна війна характеризується веденням воєнних дій 3 одночасним використанням широкого спектру політичних, економічних та інформаційно-пропагандистських заходів.

Левченко О. у роботі “Еволюція гібридної війни Російської Федерації проти України" [7] зазначив, що у гібридній війні комплексно застосовуються: дипломатичні, інформаційні, ідеологічні, економічні та частково військові засоби. Військова складова полягає у використанні комбінації збройних сил, нерегулярних формувань та невійськових сил у сполучені з діями сил спецоперацій. Об'єкти впливу: населення, органи державної влади, збройні сили та інші силові структури, економіка й фінансова система. Гібридна війна ведеться за певним планом, виконанням низки послідовних і взаємозалежних етапів. Етапи можна поділити на три фази:

перша - підготовча фаза;

друга - активна фаза;

третя - закріплююча фаза.

Ліпкан В. у роботі “Сутність гібридної війни проти України” [8] представив що Гібридна війна це цілеспрямований процес встановлення зовнішнього управління альфа суб'єктом над об'єктом управління, встановлення тотального контролю над сферою державного управління, в якому вирішальну роль відіграють інформаційні засоби (одна домінантна група управління підкорила іншу соціальну групу при цьому не встановлюючи повного та тотального контролю над суверенітетом та територією, іншими важливими але не життєво необхідними атрибутами, супроводжується капітуляцією збройних сил).

Рижков І. у роботі “Композитна стратегія протидії мережевим та гібридним викликам сучасного тероризму" [10] дав визначення гібридної (компаундної) війни, як військової стратегії, яка передбачає використання різних дій воєнного, дипломатичного, інформаційного характеру, спрямованих на досягнення стратегічних цілей. Зміна пріоритетів у бік використання невійськових збройних формувань пов'язана задля ускладнення кваліфікації дій агресора 3 позиції міжнародного права.

У посібнику [1] під редакцією Агаєва $\mathrm{H}$. “гібридна війна", в найзагальнішій формі за думкою авторів, визначена як військова агресія однієї держави проти іншого, зовні замаскована під внутрішньополітичний конфлікт в державі - жертві агресії. Ключовою особливістю "гібридної війни" $\epsilon$ поєднання двох здавалося б взаємовиключних чинників: прямого ведення війни агресором (від ухвалення усіх політичних і навіть оперативних військових рішень до прямої участі в бойових діях регулярних частин збройних сил) i категоричного публічного невизнання агресором своєї участі в конфлікті.

3 аналізу досліджень українських авторів, щодо визначення терміну "гібридної війни" можна зауважити: по-перше дослідження стосуються В основному протистоянню України з Росією (гібридних дій Росії проти України), по-друге мають оборону направленість (держава $є$ жертвою агресора), по-третє розкривають зміст терміну “гібридна війна” тільки з огляду на питання, які розглядаються автором у роботі.

Для більш змістовного розкриття терміну необхідно відповісти на наступні питання: масштаб, мета, стратегія, сторони, які протистоять, об'єкти впливу, методи, способи дій, хто керує процесом.

Таким чином можна визначити, що “гібридна війна" - $є$ сучасна версія війни, як боротьби держави за своє минуле, сучасне i майбутнє, це війна нового покоління. Вона 
являє собою геополітичне явище. $\mathrm{y}$ геополітичному просторі кожна держава вибудовує свій проєкт, якій визначає місце держави в світі, їі національні інтереси. Виходячи з національних інтересів будуються взаємовідношення 3 іншими державами (визначення їх місця і ролі в забезпеченні національних інтересів держави).

Одним 3 геополітичних результатів “гібридної війни" $€$ зникнення 3 історії людства держав (Радянського Союзу; Німецької Демократичної Республіки, Республіки Югославія, Чехословацької Республіки).

3 огляду на вищевикладене за своїм масштабом “гібридна війна" відноситься до стратегічних дій. Вона $\epsilon$ перманентною (безперервною) та всеосяжною. Підтвердження цього ми знаходимо в однієї з публікацій "NATO Review magazine", де зазначається: “Термін “гібридна війна"... був прийнятий усіма головними воєнними державами и став базисом сучасної воєнної стратегії..." [2]. На сьогоднішній час вислів “бажаєш миру - готуйся до війни” воєнними теоретиками, з огляду на сучасну парадигму, замінений на "бажаєш миру - воюй".

За мету можна визначити просування та захист національних інтересів держави. Через категорію інтересу досягається взаємозв'язок між політикою, війною i економікою. Британській прем'єр-міністр XIX ст. лорд Генрі Пальмерстон висказав знамениту думку про те, що держава не може мати ані постійних друзів, ані постійних ворогів, але одні лише постійні інтереси. Тому війна ведеться не за абстрактні ідеї, а за конкретну вигоду. Отже, військова доктрина і все військове будівництво в державі в цілому повинні виходити з необхідності просування національних інтересів.

Стратегією “гібридної війни" $\epsilon$ використання воєнних і невоєнних методів в ході гарячої війни або холодної війни (культурного співробітництва) спрямованих на досягнення військових, цивільних, політичних, економічних цілей в інтересах держави. Вона пропонує усунення, як максимум і деструкцію й ослаблення, як мінімум, суб'єкта який несе загрозу національним інтересам. Кінцева мета стратегії - стримування, хаотизація і деструкція держави противника.

Класичні стратегії виражені в китайській стратагемі. Стратагема - це "хитромудрий план, оригінальний шлях до досягнення військових, цивільних, політичних, економічних або особистих цілей". Стратагема являє собою сплав стратегії 3 умінням розставляти приховані від противника пастки.

Традиційними принципами китайської стратагеми є:

- “i i нжи i” ("Керувати варварами 3 допомогою варварів"),

- “i i гун i" ("Атакувати варварів за допомогою варварів"),

- “i i чжі i” ("Стримувати варварів за допомогою варварів").

Сторонами "гібридної війни" $є$ держави, коаліція держав, глобальні та транснаціональні корпорації, наднаціональні утворення (типу “deep state").

Об'єктами впливу можна вважати: систему державного управління, інфраструктуру, система життєзабезпечення, суспільство, силові структури.

Методи за якими здійснюється вплив можна поділити на: методологічний, хронологічний, фактологічний, економічний, геноциду, силовий.

Основні способи які будуть використовуватися це:

силові - війни, втому числі громадянська війна розв'язана в середини держави (зрощування сепаратизму), збройні конфлікти, “кольорові революції", тероризм, кримінал;

геноциду - наркотики, алкоголь, тютюн, медичні препарати та продукти харчування (які визивають онкологічні захворювання, безпліддя й інші пагубні наслідки для здоров'я людини та ії нащадків), антисоціальні програми (скасування соціальних програм);

економічні - кредити під відсотки, санкції проти всіх або окремих секторів економіки, закриття ринків, блокування визначених 


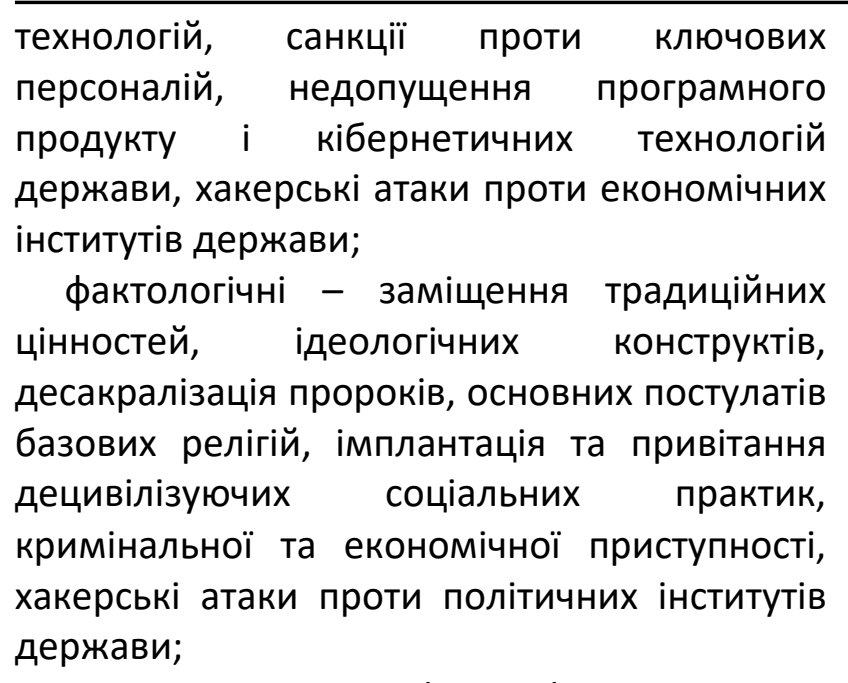

хронологічні - фальсифікація історії держави (нав'язування своєї точки зору на історичні події), порушення психології народу, соціальних зв'язків, почуття патріотизму;

методологічні - нав'язування хибної філософії, хибного світобачення, порушення зв'язків з світобудовою.

Виходячи з вище розглянутого можна визначити що:

Гібридна війна є агресією, яка представляє собою сукупність узгоджених i взаємопов'язаних за метою, завданнями, місцем, і часом одночасних або послідовних стратегічних та тактичних дій збройних сил, інших міністерств та відомств держави (коаліції держав), структурних підрозділів транснаціональних корпорацій, транснаціональних банків (наднаціональних утворень) які проводяться за єдиним замислом і планом під єдиним керівництвом із залученням визначених сил та засобів, метою якої $\epsilon$ просування своїх національних (транснаціональних) інтересів за рахунок національних ресурсів та територіальної цілісності інших держав.

інтересів, населення, системи державного управління, територіальній цілісності, традиційних цінностей, історії та забезпечення сприятливих умов для розвитку людини та держави. Гібридні дії повинні здійснюватися як у відповідь на дії агресора так і упереджуючи їх.

у подальших дослідженнях питання протистояння у цьому виду конфлікту повинні зайняти відповідне місце на наукових семінарах, конференціях, як на відомчому так і міжвідомчих рівнях. На обговорення доцільно винести ключові проблеми нових конфліктів сучасності, в тому числі: що таке гібридна війна і гібридні загрози, характеристики гібридної війни (актори, цілі, стратегії, наміри), можливі заходи протидії гібридним загрозам на міждержавному та національному рівнях.

\section{Список використаних джерел}

1. Агаєв Н. А., Герасименко М. В., Дикун В. Г., Стасюк В. В. “Гібридна війна" Росії проти України: інформаційний вимір: навч. посібник. ТОВ "7БЦ“, С. 189.

2. Hybrid war - does it even exist? URL: NATO Review magazine.
http://www.nato.int/docu/Review/2015/Als o-in-2015/hybrid-modern-future-warfarerussia-ukraine/.

3. Mc Gregor Knox and Williamson Murray, Eds. The dynamics of Military Revolution 13002050. Cambridge, Cambridge University 
Press, 2001.

4. Frank G. Hoffman. Conflict in the 21-th Century: the Rise of Hybrid Wars. Arlington, VA: Potomac Institute for Policy Studies, December 2007 [Електронний ресурс] URL: www.potomacinstitute.org/images/ stories/publications/potomac_hybridwar_01 08.pdf.

5. Курбан А. Інформаційні війни в соціальних онлайн-мережах (Новые формы агрессии. Форум “Современные гибридные войны”. Телеком, военная связь. 2017.

6. Радковець Ю. Уроки дворічної “гібридної війни" Росії проти України. БІНТЕЛ. Журнал геополітичної аналітики. №2. 2016. Київ,
ТОВ “Друкарня Бізнес поліграф”, 2016. $128 \mathrm{c}$.

7. Левченко О. В. Еволюція гібридної війни Російської Федерації проти України. Наука і оборона, 2017, №2.

8. Ліпкан В. А. Сутність гібридної війни проти України. Імперативи розвитку цивілізації. 2015, №2.

9. Компанцева Л. Ф. Інформаційні vs організаційні війни. Імперативи розвитку цивілізації. 2015, №2.

10. Рижков І. М. композитна стратегія протидії мережевим та гібридним викликам сучасного тероризму. Імперативи розвитку цивілізації. 2015, №2.

\title{
Гибридная война - современная стратегия противостояния
}

\author{
Олег Посмитюх * 1 А; Николай Павлунько 2 А; Вадим Ковальский 3 А \\ * Corresponding author: ${ }^{1}$ к.в.н., доцент, e-mail: olegposmit777@gmail.com, ORCID: 0000-0002-4467-9532 \\ ${ }^{2}$ K.B.H., e-mail: olegposmit777@gmail.com, ORCID: 0000-0001-8255-6245 \\ ${ }^{3}$ e-mail: olegposmit777@gmail.com, ORCID:0000-0002-0234-4304
}

А Национальный университет обороны Украины имени Ивана Черняховского, пр-кт Воздухофлотский, 28, г. Киев, 03049, Украина

\begin{abstract}
Аннотация
В статье рассмотрены научные публикации из опыта противостояния против гибридных угроз государств мира, на основе данных материалов определены цели, содержание гибридной войны и сформулированы ее определения.

Появление и развитие новых стратегических факторов породило концепт гибридной войны как стратегии противостояния между государствами, который невозможно в чистом виде отнести ни к войне, ни к миру. Термин "гибридная война" впервые предоставлено в военных документах США и Великобритании в начале XXI столетия.

В сегодняшних войнах и вооруженных конфликтах, как в Украине, так и в других регионах мира проявляются доминирующие важные черты и характеристики войн будущего. Они все больше приобретает гибридный (“комбинированный”) характер. В настоящее время опыт АТО и ООС, показывает, что мы столкнулись с войной гибридного характера, которую не можем закончить традиционными методами.
\end{abstract}

Ключевые слова: гибридная война, государство, национальная безопасность, вооруженный конфликт, стратегические действия.

\section{Hybrid warfare is a modern strategy of confrontation}

\author{
Oleg Posmitukh ${ }^{1 \text { A }}$, Mykola Pavlunko ${ }^{2}$ A , Vadim Kovalskyy 3 A \\ * Corresponding author: ${ }^{1}$ PhD, assistant professor, e-mail: olegposmit777@gmail.com, ORCID: 0000-0002-4467-9532 \\ 2 PhD, e-mail: olegposmit777@gmail.com, ORCID: 0000-0001-8255-6245 \\ ${ }^{3}$ e-mail: olegposmit777@gmail.com, ORCID:0000-0002-0234-4304 \\ A National Defence University of Ukraine named Ivan Chernyakhovsky, 28, Povitroflotsky Ave., Kyiv, 03049, Ukraine
}

\section{Abstract}

The article considers scientific publications on the experience of confronting hybrid threats to the world. On the basis of these materials the purposes, the maintenance of hybrid war is 
defined and its definition is formulated.

The emergence and development of new strategic factors gave rise to the concept of hybrid warfare as a strategy of confrontation between states, which cannot be purely attributed to either war or peace. The term "hybrid war" was first introduced in US and British military documents at the beginning of the 21st century.

In today's wars and armed conflicts, both in Ukraine and in other regions of the world, the dominant important features and characteristics of the wars of the future are manifested. They are increasingly becoming a hybrid ("combined") nature. At present, the experience of antiterrorist operation and environmental protection shows that we are facing a hybrid war, which we cannot end with traditional methods.

Keywords: hybrid war, state, national security, armed conflict, strategic actions.

\section{References}

1. Ahaiev N. A., Herasymenko M. V., Dykun V. H., Stasiuk V. V. "Hibrydna viina" Rosii proty Ukrainy: informatsiinyi vymir: navch. posibnyk. TOV "7BTs", S. 189.

2. Hybrid war - does it even exist? Available from: NATO Review magazine. Available from: http://www.nato.int/docu/Review/ 2015/Also-in-2015/hybrid-modern-futurewarfare-russia-ukraine/.

3. Mc Gregor Knox and Williamson Murray, Eds. The dynamics of Military Revolution 13002050. Cambridge, Cambridge University Press, 2001.

4. Frank G. Hoffman. Conflict in the 21-th Century: The Rise of Hybrid Wars. Arlington, VA: Potomac Institute for Policy Studies, December 2007. Available from: www.potomacinstitute.org/images/stories/ publications/potomac_hybridwar_0108.pdf.

5. Kurban $A$. Informatsiini viiny $v$ sotsialnykh onlain-merezhakh (Novble formb ahressyy. Forum "Sovremennue hybrydnue voinb". Telekom, voennaia sviaz. 2017.

6. Radkovets Yu. Uroky dvorichnoi "hibrydnoi viiny" Rosii proty Ukrainy. BINTEL. Zhurnal heopolitychnoi analityky. №2. 2016. Kyiv, TOV “Drukarnia Biznes polihraf”, 2016. $128 \mathrm{~s}$.

7. Levchenko O. V. Evoliutsiia hibrydnoi viiny Rosiiskoi Federatsii proty Ukrainy. Nauka i oborona, 2017, №2.

8. Lipkan V. A. Sutnist hibrydnoi viiny proty Ukrainy. Imperatyvy rozvytku tsyvilizatsii. 2015, №2.

9. Kompantseva L. F. Informatsiini vs orhanizatsiini viiny. Imperatyvy rozvytku tsyvilizatsii. 2015, №2.

10. Ryzhkov I. M. kompozytna stratehiia protydii merezhevym ta hibrydnym vyklykam suchasnoho teroryzmu. Imperatyvy rozvytku tsyvilizatsii. 2015, №2. 